\title{
TRACING THE PRECEPT OF MOTION FROM THE ANCIENT TO THE SCIENTIFIC REVOLUTION
}

\author{
MANJUSHREE CHAUDHURI ${ }^{1} \&$ Dr. SEEMA AGNIHOTRI ${ }^{2}$ \\ ${ }^{1}$ Research Scholar, Amity Institute of Education, AUUP, Noida, India \\ ${ }^{2}$ Assistant Professor III, Amity Institute of Education, AUUP, Noida, India
}

\begin{abstract}
Philosophers since times immemorial have endeavoured to comprehend the reality of nature and within it the primacy of "motion". An attempt in this enquiry is being made, to sieve through the corpus of thought, relating to the ontology of motion through primary and secondary data. The article traces the systematic attempt over the ages to cogitate on and formulate the concept of motion, beginning with the ancient mechanistic view, and culminating in Newton's work.

In this exposition we scrutinize the shift from positivism, to what Husserl called idealization to account for the scientific theories of motion. In Newton's own words, "Since the ancients esteemed the science of mechanics of greatest importance in the investigation of natural things, and the moderns rejecting substantial forms and occult qualities, have endeavoured to subject the phenomenon of nature to the laws of mathematics, as far as it relates to philosophy" (Newton,1952,p.1).

In the spirit of a larger inquiry, we have tried to identify whether any of the thought processes emerging out with the onset of the Scientific Revolution could be gleaned in any of the preceding historical moments of intellectual investigation.

KEYWORDS: Ontology of Motion, Positivism, Ancient View (Mechanics), Modern View (Mechanics), Idealization, Vaiśeșika
\end{abstract}

Received: Jun 09, 2020; Accepted: Jun 29, 2020; Published: Aug 03, 2020; Paper Id.: IJMPERDJUN2020592

\section{INTRODUCTION}

Tracing the precept of motion from the ancient to the scientific revolution

"The process of scientific discovery is in effect a continual flight from wonder"

-Einstein

The world of science was filled with excitement when on $4^{\text {th }}$ July, 2012, CERN (Conseil Européen pour la Recherche Nucléaire) revealed the discovery of the so called "God particle", confirming the existence of Higgs boson, which when explained using Brout-Englert-Higgs mechanism was purported to bestow mass to the elementary particles it interacted with. Perceiving mass in a state of continuous flux and evolution was necessary to conceptualize motion, according to Dialectical Materialism. Engels went further when he said "motion without matter is unthinkable" (Engels, 1947, p.36). This statement was refuted when the existence and motion of mass-less photon could be explained by the famous Einstenian equation: $\mathrm{E}^{2}=\mathrm{p}^{2} \mathrm{c}^{2}+\mathrm{m}^{2} \mathrm{c}^{4}$. Further an Idealist, who conceived the world as his idea or sensation, "would not even think of denying that the world is motion, i.e., the motion of my thoughts, ideas, sensation" (Lenin, 1972).The perennial search for the existence and nature of "motion" has thus been a central concern for homosapiens. 


\section{ANCIENT MECHANISTIC WORLD VIEW}

The Ancient Greek, Indian and Roman philosophers analyzed the essence of motion and investigated its epistemological and ontological domains.

Heraclitus (535-475B.C.E.), who belonged to an aristocratic family in Ephesus (present- day Turkey), eschewed worldly life for a solitary existence devoted to contemplating and deliberating on the various aspects of philosophy. $\mathrm{He}$ emphasized the impermanence of objects, their change and motion. His expression "Panta Rhei" or "All things flow" and his observation to the effect that if a person steps into the same river, he encounters new water, reiterates this fact (Kahn, 1979).

Parmenides, a metaphysical monist was born around 515 B.C.E in Elea (present-day Velia). "Way of Truth" is a section of his solitary poem "On Nature", which with the use of deductive a priori arguments enunciates motionless state of existence or motion being a mere apparition.

Ontological Pluralism was a tool used by the Elean philosopher Zeno, a close associate of Parmenides, to defend his philosophy. Born around 490 B.C.E. he wrote a book on Paradoxes, a part of which has survived. He articulated four paradoxes pertaining to motion namely "The Dichotomy", "Achilles and the Tortoise", "The Arrow", and "The Stadium". The underlying principle of all these paradoxes was to prove that absurd consequences result when we predict the existence of the infinite instead of one. Aristotle in his interpretation of "The Dichotomy" explains that the motion becomes nonexistent if the magnitude (displacement and time) is divided infinite times and if each path is traversed. Explaining the paradox of "The Arrow" he avers that an arrow when flying is at rest if we assume time comprising of moments, and if every entity occupying identical space was at rest, and continuously in a now then the flying arrow would be motionless (Aristotle, 1991, p.110).

\section{Vaiśeșika Philosophy}

At approximately the same time in India, Kanāda propounded the Vaiseșika philosophy which became one of the six prominent schools of classical Indian Philosophy. Vaiśeșikasūtra (Treatise) deals with various aspects of physics and metaphysics. This sage- scientist was born around 600 B.C.E. in Banaras, and he was also known as Kāśyapa or Ulūka according to the tradition preserved in the Buddhist writings (Chakrabarty, 2003, p.28). There are three hundred and seventy three aphorisms in Vaiśeșikasūtra divided into ten Adhyāaya (chapters),each having two Āhnika (sections).The term Vaiśeșika is derived from viśeșa which means difference, and the doctrine is so designated ,because according to it, diversity and not unity, is at the root of the universe ( Hiriyanna,1932 as cited in Kumar,2019,p.78). Atomic Theory is the foremost contribution of Vaiśeșika Darśana (Philosophy), and appropriately the founder was named, Kaṇāda (Kaṇān attīti Kanāadah, the Atom-eater) (Kumar, 2019, p.79).The Vaiśeșika Darśana is basically an ontology since it deals with the enumeration and delineation of the ultimate constituents of the universe. It is a system of descriptive metaphysics concerned with pluralistic realism (Kumar, 2019, p.67). Various concepts and theories like Dharma and its purpose, liberation, seven categories to explain the diversity of the universe, material and non material substances like space, time, soul and mind, nature of sound, atomic theory, theory of chemical action, causation, consciousness and cognition, some properties of metal, types of proofs and fallacious arguments, dream, gravitation and laws of motion have been put forth by Kaṇāda. 


\section{Motion and its Cause}

In the seventh sūtra (aphorism) of the first section of the first chapter, Kanāada describes five types of motion (karma), namely as upward (utkșepaṇam), downward (avakșepaṇam), contraction (ākuñchanam), expansion (prasāraṇam), and rectilinear motion (gamanam)1(Sinha, Nandalal (Eng. Trans.) 1986).

Vaiśeșika delineates force as the common cause of conjunction, disjunction and motion. ${ }^{2}$

Kaṇāda subsequently identified the force of gravity as being responsible for the falling of objects, thus theorizing that "In the absence of contact (with any material) free fall (results) due to force of gravity" or samyogābhāve gurutvāt patanam (Vaiśeșikasūtra,5.1.7). He reiterates when he claims that in the absence of force, an arrow falls due to gravity. ${ }^{3}$

The property of an attribute (guṇa) has been clearly described in the Vaiśeșika Treatise as dravyāśṛayaguṇavān saṁyogavibhāgeșvakāraṇamanapekṣa iti guṇalakṣanam

(Vaiśeșikasūtra, 1.1.16)

Intrinsic to the substance, not possessing characteristic, not an independent cause of contact or separation are the features of an attribute. Attributeness is the causality present in something possessing genus and is devoid of combinative causality and non-combinative causality towards conjunction and disjunction combined (Sinha, Nandalal (Eng. Trans.) 1986). On the other hand the ancient Indian philosopher Praśastapāda (6th century C.E) in his commentary and exposition on the Vaiśeșikasūtra titled Praśastapādabhāṣyam, emphasized that the change in motion is due to the impressed force, is proportional to it and acts in the same direction.

tatra vego mūrtimatsu pañcasu dravyeșu nimitta-viśeșāpekșāt karmaṇo jāyate

niyata-dikkriyā-prabandha-hetuh sparśavad-dravya-samyoga-viśeșavirodhī kvacit

kāraṇa-guṇapūrva-krameṇotpadyate (Praśastapādabhāṣyam, 1977,p.646-647)

Thus any state or attribute of a body does not contribute to a change in its state, causing motion or a change in the motion, until a force is impressed upon the body.

The Vaiśeșika aphorism; nodanaviśeșādudasanaviśeșah(Vaiśeșikasūtra, 5.1.10) explains that a particular impulse is responsible for a particular upward movement (of a body).One can decipher that if the Impulse is increased then the magnitude of the upward movement is increased leading to a change in its velocity or Impulse is proportional to the change in an object's velocity.

Thus Impulse $\alpha$ Change in velocity-

If we interpret (i) mathematically then:

\footnotetext{
${ }^{1}$ utkṣepaṇamavakṣepaṇamākuñcanai் prasāraṇaṁ gamanamiti karmaṇi

${ }^{2}$ saìnogavibhāgavegānāim karma samānam|

${ }^{3}$ samiskārābhāve gurutvāt patanam

Vaiśeșikasūtra, 1.1.20 (Chakrabarty,2003)

Vaiśeșikasūtra,5.1.18 (Chakrabarty,2003)

According to Apte, samskārāa (impression) refers to one of the 24 qualities or guna recognized by Vaiśeșika. It is of three kinds: Bhāvana (concept or disposition), vega (force) and sthitisthāpaka(elasticity) (Apte, 1959).
} 
Force $\mathrm{x}$ time $\alpha$ Change in velocity; as Impulse (I) is Force (F) multiplied with time (t), and if we take the change in velocity as $\Delta \mathrm{v}$ then

$\mathrm{F} \times \mathrm{t} \alpha \Delta \mathrm{v}$

$\mathrm{F} \alpha \frac{\Delta \mathrm{v}}{\mathrm{t}}$

F $\alpha$ a where " $a$ " is the acceleration of the body. ( $\left.\frac{\Delta v}{t}=a\right)$

Thus we can interpret the aphorism to connote that the force applied is directly proportional to the acceleration produced in the body as a result of its impact.

Kaṇāda's next Law of motion is succinctly put as "kāryavirodhi karma” (Vaiśeșikasūtra, 1.1.14).Deciphered it implies "Action is opposed by its effects" (Sinha, Nandalal (Eng. Trans.) 1986) or Action is equal and opposite to the reaction it produces.

Expounding on the Atomic Theory, Vaiśeșika posits that at the very inception of creation, aṇu(atom) is put into motion by an unseen force ( $a d r s s ̦ t a)$, which leads to the combination of two atoms producing dyad (dvyaṇka).Further, three dyads combine to form a triad ( tryaṇuka, trasarenu or truți) which is the smallest visible form of matter. Four triads join to form a tetrad (caturaṇuka) leading to the creation of gross bodies. Praśastapāda in his Padārthadharmasamigraha has given details of the formation of gross worldly objects from the four types of atoms (Kumar, 2019, p.71).

\section{Theory of Atomism}

For the second time in this world, the theory of Atomism was once again broached by a team of Greek philosophers, Leucippus and Democritus, variously said to be born in Abdera or Miletus in the fifth century B.C.E. (Laertius, n.d., p.439\& p.443). From the secondary sources like the disquisition of Aristotle, Democritus is said to have built on the views of his pedagogue Leucippus (Taylor, 1998).

Leucippus pronounced that the sum of the things was unlimited, and they all (empty or full) get transformed into one another. The atoms while moving fall into voids, and get entangled with one another. There occurs subsequent qualitative changes in them due to the rearrangement or addition of atoms, leading to even the formation of stars (Laertius, n.d.,p.440). “Atomon" (indivisible), Democritus posited, were the building blocks of all animate and inanimate objects. These solid entities of various shapes and sizes were in eternal motion in an infinite void, either combining or repelling each other to form macroscopic objects. "The void was necessary for motion but is characterized by "what is not", thus violating the Eleatic principle that "what-is-not cannot be" (Taylor, 1998). Democritus had travelled to Egypt to learn Geometry from the priests, and had also gone to Persia to visit the Chaldaeans according to Demetrius's book "On Men of the same Name", and Antisthenes' writing "Successions of Philosophers". His association with the Gymnosophists of India was also asserted (Laertius, n.d., p.445).

\section{Actuality Qua Potentiality}

The subsequent historical precursor philosophizing on motion was the Greek philosopher Aristotle, born in Stagiros in 384 B.C.E. A neophyte at Plato's Academy in Athens, his thirty-one surviving work subsumed in “Corpus Aristotelicum” can be bifurcated into four branches incorporating organon (logic e.g. De Interpretatione), theoretical (e.g. Physics, De Caelo etc.), practical (e.g. Eudemian Ethics, Politics etc.) and productive (Rhetoric and Poetics) sciences which he called 
epistêmai. Aristotle defined motion as "Actuality of that which potentially is", which he documented in Physics. He theorized that the velocity of a freely falling body was inversely proportional to the density of the medium and directly proportional to the weight of the body (Rovelli, 2015,p.26). Aristotle argues in chapter six of "Physics", that there must exist an ultimate static mover of all the movements in the cosmos. The rationale of this eternal cosmological motion he claims, can be based on the ontological premise of a causal link between this static mover and a single continuous everlasting movement, all self movers, and those that alternate between movement and rest (Blyth, 2015, 160).

\section{Fluid Mechanics}

Born into nobility in 287 B.C.E., Archimedes was the son of the mathematician and Astronomer named Phidias of Syracuse (Russo, 2013).His bequest led Descartes to declare, “Archimedes' demand of one static point was enough for him to move the whole earth". Archimedes' famous ability with machines did not have to do only with his ability as an engineer, but was a result of his mathematical acumen, leading to various theories and their proofs (Vampoulli, 2010, p.333-334). Archimedes in his book "On Floating bodies-Book I and II", laid the foundation of the "Laws of floatation" which are used for varied practical purposes like the construction of a ship, a hydrometer etc. In his proposition he states that if a solid body lighter than a fluid is forcibly immersed in it, the solid will be driven upwards by a force equal to the difference between its weight, and the weight of the fluid displaced. He further says that a solid heavier than a fluid, will when placed in it descend to the bottom, and the solid will when weighed in the fluid be lighter than its true weight by the weight of the fluid displaced. Those solids whose weight is equal to that of a fluid, when let down will be immersed so that they do not project above the surface, nor sink lower (Archimedes, 1897, pp.253-258).

\section{Mūlamadhyamakakārikā}

Nāgārjuna, a Mahāyāna Buddhism sophist, variously placed at the end of the first century C.E. to the third century C.E.(Ruegg, 1981, p.4) was the founder of Mādhyamika (Middle Way) school,and authored the Mūlamadhyamakakārikā (Philosophy of the Middle Way). The Madhyamakaśāstrastuti attributed to Candrakīrti has referred to eight works by Nāgārjuna: the Yuktiṣaștikā (reasoning dealing with non-apprehension), the Kārikās of Madhyamaka (verses for the middle way), the Śñnyatāsaptati (exposition on emptiness), the Vigrahavyāvartan̄̄(Precluding Discord), the Vaidalyasūtra and Vaidalyaprakaraṇa (dealing with eristic), the Ratnāvalī (paraenetic discourse) the Sütrasamuccaya (anthology of canonical texts), and Samstutis (hymns). This list covers not only much less than the grand total of works ascribed to Nāgārjuna in the Chinese and Tibetan collections, but it does not even include all such works that Candrakirti has himself cited in his writings (Ruegg, 1981,pp.8-31).

Born in South Kosala or Vidarbha (Ruegg, 1981, p.4), Nāgārjuna's doctrine of Śūnyatā (emptiness) of various phenomena, declaring their non-permanence, dependency and change was extended to the concept of rest and motion, declaring them as inexplicable. In the second chapter of Mūlamadhyamakakārikā, Nāgārjuna undertakes the examination of the moved and not moved (Gatāgata-parīkșā) and asserts "Gatam na gamyate tavād agatam naiva gamyate /gatāgatavinirmuktam gamyamānam na gamyate" i.e. What has been moved is not moving. What has not been moved is not moving. Apart from what has been moved and what has not been moved, Movement cannot be conceived (Nāgārjuna, 1991, p.118).He further states, "Ceștā yatra gatis tatra gamyamāne ca sā yatah̆/ na gate nāgate ceștā gamyamāne gatis tatah" i.e. wherever there is movement, there is motion. Hence movement is in the present moving, and neither in the moved nor in the not moved, implying that motion is available in the present moving. Where there is change, there is motion. Since there is change in the moving, And not in the moved or not-moved, Motion is in that which is moving 
(Nāgārjuna, 1991, p.119). In the third verse he posits "How would it be acceptable for motion to be in the mover? When it is not moving, it is not acceptable to call it a mover" (Garfield, 1995, p.6).By means of similar epistemic interpretations and arguments, Nāgārjuna finally concludes in the twenty fifth verse that "Neither an entity nor a non-entity moves in any of the three ways. So motion, mover and the route are non-existent" (Garfield, 1995, p.9).

\section{Revolution in Cosmological Theory}

The Greek astronomer, Aristarchus of Samos (310 B.C.E. to 230 B.C.E.), (Heath, 1913, p.299) was amongst the rarest mathematician who left to posterity his extant work "On the sizes and distances of the sun and moon", an improved Sundial and his heliocentric hypothesis. Archimedes while referring to it has quoted, "Aristarchus's hypothesis is that the fixed stars and the sun remain unmoved, and that the earth revolves about the sun in the circumference of the circle, while the sun lies in the middle of the orbit" (Heath, 1913, p.302).Nothing much is known about the life of Aristarchus leaving the fact that his hypothesis did not receive much attention, not even when Archimedes eluded to it in his book entitled the "Sand Reckoner".

\section{THE SCIENTIFIC REVOLUTION}

The Inception of the 'scientific worldview' emerged in 1543 with the publication of Nicolaus Copernicus's radical thoughts in the book "De revolutionibus orbium coelestium" which contrary to Aristotelian geocentric universe heralded a heliocentric universe, a theory which unlike Aristarchus's work became visible to the world. With the publication of Newton's "Philosophiæ Naturalis Principia Mathematica" in 1686, a final nail was put in the coffin of Aristotle's physics. The 143-year period between these two publications is usually known as the Scientific Revolution, a term coined by Alexandre Koyré (Agutter \& Wheatley, 2008, p.57).

A recent article in this year's February edition of The Astrophysical Journal highlights the novel foray into the hydrodynamical simulation of the genesis of galaxies in the Milgromian gravity, MOND (Modified Newtonian Dynamics) where it is assumed that Newton's law of Gravitation is modified under many order of magnitude of lower acceleration produced on a body as compared to the standard borderline acceleration produced as a result of its interaction with another body (Wittenburg, Kroupa, and Famaey,2020). The tryst with the unknown is as prevalent today, as it was in a world which had not conceived the concept of simulation.

\section{De Revolutionibus Orbium Coelestium}

The majestic panorama of the stars had also fascinated the polish lad Nicolaus Copernicus, born in the city of Torun in February, 1473 (Karpinski, 1945, p.344).Tutored by the famous astronomer and mathematician Albertus de Brudzewo in Cracow, Copernicus during his stay in Bologna, gradually acquired a knowledge of the Indian, Arabic, Latin and German Trigonometry (Karpinski, 1945, pp.345-346), besides garnering insights of medicine, mathematical astronomy and philosophy. He was in the meantime made the canon of Frauenburg Cathedral at the behest of his uncle, the duties of which he summarily undertook on his return to Poland in 1501.The fascination for the grandeur of the stars, their motion and the embedded mathematical theories thereof, chaperoned his detailing the apothegm of Heliocentrism in "Commentariolus", and the detailed mathematical proof in "De revolutionibus orbium coelestium", which saw the light of this world in 1543, the year of the demise of its author. 


\section{Mystery of the Universe}

One of the greatest minds, and a student of languages, theology, mathematics, astronomy and astrology, Johannes Kepler was born in the imperial city of Weil on December 27, 1571 (Caspar, 1993, p.29).As a district mathematician, and a teacher at Graz he became famous not only for the official calendars that he composed, but also for his first book, "the Mystery of the Universe" (Mysterium Cosmographicum). The major idea of Kepler of seeking a relation between the distance of the planets from the sun and their orbital period, and also the causal relation between the sun's force and the planet's motion, heralded greater vistas in the development of astronomy(Casper,1993,p.67). Kepler worked under the Danish astronomer Tycho Brahe, famous for his treasure of astronomical observations gathered through years of unstinting effort. On his demise, Kepler was instated as the Imperial Mathematician in Prague. With the help of the recently inherited treasure of his mentor, the newly invented reflecting telescope and his classical mathematical prowess, Kepler enunciated that every planet moves around the sun in an elliptical orbit, with the sun at one focus, in his treatise "Astronomia Nova". This book also contains his second law i.e. "The velocity of the planet varies with its distance from the sun in such a way that a line joining the planet with the sun sweeps out equal areas in equal intervals of time". Kepler suspected that each planetary body might have within itself a moving principle that defines time for that body and its parts. Time becomes a way in which motion is perceived and numbered, but the speed or slowness of the motion is fundamentally an expression of the strength of the moving principle. Thus time should be defined in terms of force and distance, a greater force over a constant distance results in a motion that takes less time (Donahue, 1994, 102). "The square of the time taken by any planet to make a complete orbit around the sun is proportional to the cube of its mean distance from the sun"(Russel, 1964,p.2),declared Kepler in his third law of planetary motion which he ensconced comfortably within "Harmonices Mundi" (Harmony of the world), published in 1619.Fascinated by the music or harmony of the spheres, a Pythagorean concept taught in his academy, Kepler was further influenced by Ptolemy's theory of Harmonics, and mathematically tried to reiterate the concept of harmonics associated with the planetary motion.

\section{Idealization}

Idealization was interpreted by Husserl as a procedure in which any phenomenon or aspect of the world is replaced by a mathematical concept (Wiltsche, 2017, p.154).The Italian Physicist and astronomer, Galileo Galilei (February 1564 January 1642) was the pioneer in the field of idealization called Instrumental idealization, where he replaced the phenomenon of this world e.g. laws of nature, by mathematical quantities obtained by techniques of measurement (Kvasz, 2013, p.577). Besides devising a compass, a thermo scope and a refracting telescope (which he used to observe celestial bodies), and formulating the law stating that the square of the time period of a pendulum varies directly with its length, Galileo, contrary to the Aristotelian physics, postulated that as long as the medium's resistance was neglected, a body will fall with uniform acceleration, and the distance covered would be proportional to the square of the time take by the body to travel the distance. De Motu, published posthumously, is Galileo's book on motion, and also contains his views on floatation. His observations as contrasted to the Aristotelian philosophers were tutored by mathematical reasoning imposing specific and precise conditions. In the published Florentine dispute on floating bodies with Aristotelian philosophers, he alleges; "heaviness brings forth a cause well known to our senses, because we can very easily ascertain whether ebony, for example, or fir, is heavier or less heavy than water; but who will make manifest to us whether the element of earth, or that of air, has predominance in them?'(Dyck, 2006, p.121 ). He validated that the objects which were heavier than water will sink, while those which were lighter than water will float in it. 


\section{Cartesian World View}

Cartesian ontological idealization of objects theorized by the French scientist and philosopher, René Descartes, born in La Haye, (1596C.E. - 1650C.E.) consisted in replacement of the objects of life world by extended bodies obtained in the process of ontological reduction of reality ( Kvasz,2013,p.577).The famous adage "Je pense, donc je suis", (I think, therefore I am) was Descartes' life philosophy, revealed to the world in his treatise, "Discourse on the Method", leading to his evolving the Coordinate (Cartesian) geometry, idea of exponent, planetary motion, conservation principle and the laws of nature. Encapsulated in his work "Le Monde", unpublished during his lifetime, his Laws of Nature were finally presented to the world through his second work entitled "Principia Philosophiæ" or the Principles of Philosophy. His first two Laws of Nature as stated below deal with a single object:

The First law: "Each part of matter, in so far as in it lies, always perseveres in the same state, and when once moved always continues to move".

The Second Law: "Each and every motion by itself is rectilinear, thus objects moved around a circle always tend to recede from the centre of the circle described by them". (Blackwell, 1966, p.220)

Descartes' Third law of nature or the law of conservation deals with plurality when he avers:

"On collision of one mobile body with another, if the body has less force to continue in its rectilinear path than the other body has to resist it, it will be deflected in the opposite direction, though retaining its own motion. If it has a greater force, then it will move the other body along with itself and will give as much of its motion to that other body as it loses" (Blackwell, 1966, p.224).

The Planetary motion of Descartes' entailed to explain the motion of celestial bodies by placing them in a vortex or an enormous whirling belt of material.

\section{Analytical Idealization}

Analytical idealization of action can be credited to Sir Isaac Newton, who was born in Lincolnshire, early on Christmas day, 1642. His methodology consisted of replacing the action between objects of the universe by forces acting at a distance, and described the process of continuous change of the state caused by the action of these forces (Kvasz, 2013, p.577).The scientific revolution attained an impetus when Newton mathematically described the interactions between the various bodies. Cambridge witnessed Newton conceiving Calculus, and as a scholar at Trinity college, and later as its prestigious Lucasian Professor he extended Wallis's use of infinite series to evaluate areas into what we know as binomial theorem, spreading to non-integer exponents (Westfall,1993).His foray also extended to alchemy and theology, building a reflecting telescope besides authoring a number of books and manuscripts on various topics like Optics, Calculus, Newton scale of temperature, Mathematics text based on his lecture notes, Report as master of Mint, Notes and Records of the Royal Society, Motion, Law of Gravitation etc.

In the preface of "Philosophiæ Naturalis Principia Mathematica", published for the first time in 1687, Newton records that he had chiefly considered those concepts which were related to elastic force, force of gravity, other attractive or impulsive forces, levity, and the resistance of fluids. He further elaborated on his choice of "Mathematical Principles of Natural philosophy" as the title of his treatise when he avers, "since the entire burden of philosophy seemed to subsist in it commencing from the phenomena of motions to investigate the forces of nature, and then from these forces to demonstrate 
the other phenomena; and to this end the general propositions in the first and second book were directed". In the third book, he writes, "I give an example of this in the explication of the System of the World; for by the propositions mathematically demonstrated in the former books in the third, I derive from the celestial phenomena the forces of gravity with which bodies tend to the sun and the several planets. Then from these forces, by other propositions which are also mathematical, I deduce the motions of the planets, the comets, the moon and the sea."(Newton, 1952, pp.1-2)

Newton at the inception of the first book of the "Mathematical Principles of Natural Philosophy" defines the quantity of matter, quantity of motion, innate force of matter, an impressed force, the centripetal force and its absolute quantity, the accelerative and motive quantity before he forays into his famous Axioms or Laws of motion, and the six corollaries of motion.

According to the first Law of Motion: "Everybody continues in its state of rest, or of uniform motion in a right line, unless it is compelled to change that state by forces impressed upon it."

The second Law of Motion states: "The change of motion is proportional to the motive force impressed; and is made in the direction of the right line in which that force is impressed."

Newton's third Law of motion states: “To every action there is always opposed an equal reaction: or, the mutual actions of two bodies upon each other are always equal, and directed to contrary parts". (Newton, 1952, p.14)

The foundation of Classical mechanics, thus laid down by Newton's seminal work completely dominated the world view until usurped by the emergence of Quantum Mechanics.

\section{CONCLUSIONS}

Glimpses of the concomitance in ideas of dynamics can be ascertained from the various available literary evidences. Nations and cultures throughout history have romanticized only some selective scientists and philosophers who may have just reinvented the wheel due to the diffusion of knowledge, evolution of thinking or social development resulting in wide dissemination of their writings.

The contention of the immobility of the universe, and of all objects within or the inexplicability of the concept of motion is asserted both by Zeno with the help of his paradoxes, and by Nāgārjuna in his treatise Mülamadhyamakakārikā, through dialectical reasoning.

Synchronicity of ideas is envisaged in the field of Atomic Theory. While Kaṇāda postulated it in 600B.C.E, Democritus espoused it in the $5^{\text {th }}$ century B.C.E. According to Demetrius, Democritus had interacted with the philosophers of India during his travel. Can we postulate the emergence of this twin idea in Greece as a result of his interactions during his sojourn or is it the cosmic motion of ideas?

It wouldn't be incorrect to refer to Copernicus as Pneumatikos, his ecclesiastical propensity due to his position as a canon, notwithstanding. His confession in the original draft of "De Revolutionibus Orbium Coelestium", that Aristarchus was the original founder of Heliocentric Universe was a proof of this propensity.

Galileo's lifelong admiration for Archimedes propelled him to reaffirm Archimedes' principle in his work "De Motu", but he later used visuo-spatial components to explain some extraordinary deviations which he had observed, till the time he became visually impaired. 
Continuing with the spirit of a larger inquiry, one finds that the idea of the concept of inertia germinated first of all in the mind of the great scientist- philosopher Kanāada in the $6^{\text {th }}$ century B.C.E., when he enunciated : "Vegah nimittaviśeșāpekșāt karmaṇo jāyate /niyata-dikkriyā-prabandha-hetuḥ"'(Praśastapādabhāṣyaṃ,1977,p.646-647).This implied that any state or attribute of a body does not contribute to a change in its state, causing motion or a change in the motion, until a force is impressed upon the body.

After approximately, 2100 years, mankind once again started investigating this concept. Galileo Galilei was credited for the rediscovery of this concept of inertia, though he did not consider the notion of inertia as rectilinear but circular. Galileo also restricted the application of the principle of inertia to smooth horizontal surfaces. René Descartes, born after thirty two years, postulated that the inertial motion is rectilinear and that the principle of inertia applies to all motions (Kvasz, 2013, p.556). The two laws recorded by Descartes can be considered the forerunners of Newton's law of Inertia i.e. "Everybody continues in its state of rest or of uniform motion in a right line, unless it is compelled to change that state by forces impressed upon it" (Newton, 1952, p.14).

While Newton in the $17^{\text {th }}$ century stated his second law of motion as "the change of motion being proportional to the motive force impressed", Kanāa'da's aphorism of the $6^{\text {th }}$ century B.C.E. could be deduced to mean that the force applied is directly proportional to the acceleration produced in the body as a result of its impact. Kanāda's Law of motion "kāryavirodhi karma" (Vaiśeșikasütra, 1.1.14) or "Action is equal and opposite to the reaction it produces." rings again in the universe in the form of Newton's third law: "To every action there is always opposed an equal reaction”(Newton, 1952, p.14).

Philosophy of Physics has been ubiquitous in its quest for comprehending the reality of this universe. Whether the metaphysical quest for scrutinizing the nature of motion or post-metaphysical search for its potential, the philosophical development of the concept of motion has been a continuous process of untangling of logic, either with the help of rules or views.

While stating his fourth rule of reasoning in philosophy, Newton takes an anti-hypothetical stance when he expounds that "In experimental philosophy we are to look upon propositions inferred by general induction from phenomena as accurately or very nearly true, not with standing any contrary hypotheses that may be imagined, till such time as other phenomena occur, by which they may either be made more accurate, or liable to exceptions" (1952, p.271). On the other hand, every cognition is perceptible in Nyāya-Vaiśeșika view; it is held to be perceived by a cognition other than itself which immediately follows the first one: it is sometimes called introspection, inward perception or cognition after a cognition or anuvyavasāya (Kumar, 2019, p.100).

It is surprising to observe while specifically comparing Kaṇāda and Newton, that aphorisms or axioms that were advanced more than two millennia ago were again installed in a new framework id est., a mathematical one. One wonders then whether there exists a cosmic cognitive cycle leading to re-emergence of epistêmê through the ages or is it mere Stigler's law of eponymy! 


\section{ACKNOWLEDGEMENT}

We would like to place on record our sincere gratitude and indebtedness to Professor Purushottama Bilimoria for his valuable and constructive suggestions, and for sparing his precious time for editing an earlier version, although any error is our own and should not tarnish the reputation of the esteemed professor.

We would also like to express our immense appreciation and gratitude to Prof. Shashi Prabha Kumar, for sparing her valuable time to expound on the various aphorisms of Vaiśeșika, and providing us the primary and secondary sources of the literature pertaining to Vaiśeșika.

Professor Purushottama Bilimoria is Editor-in-Chief of two journals, Sophia and the International Journal of Dharma Studies. He is also the Honorary Professor of Philosophy and Comparative Studies at Deakin University besides being the Visiting Professor at the University of California, Berkeley. Professor Shashi Prabha Kumar is currently the dean at Sri Shankaracharya Sanskrit Mahavidyalaya, BharatiyaVidya Bhavan situated in Delhi.

\section{REFERENCES}

1. Agutter,P. S.\&Wheatley,D. N.(2008). Thinking about Life: The History and Philosophy of Biology and Other Sciences. Dordrecht: Springer.

2. Apte, V. S., Gode, P. K., Karve, C. G., \& Abhyankar, K. V. (1900). Revised and enlarged edition of Prin. V.S. Apte'sThe practical Sanskrit-English dictionary. Poona: Prasad Prakashan.

3. Archimedes \& In Heath, T. L. (1897). The works of Archimedes. Cambridge, UK: Cambridge University Press.

4. Aristotle,.,Barnes,J.(1991).Physics, R.P. Hardie and R. K. Gaye(tr.), in The Complete Works of Aristotle: The revised Oxford translation, Vol 1,Princeton, NJ:Princeton University Press.

5. Blackwell, R. (1966). Descartes' Laws of Motion. Isis, 57(2), 220-234. Retrieved April 15, 2020, from www.jstor.org/stable/227961

6. Blyth, D. (2016). Aristotle's ever-turning world in Physics 8: Analysis and commentary. Leiden, the Netherlands: Brill.

7. Boner, P. J. (2013). Kepler's Cosmological Synthesis: Astrology, Mechanism and the Soul, Leiden, Netherlands: Brill.

8. Caspar, M. (1993).Kepler, translated by C.D. Hellman. New York, United States of America: Dover Publications.

9. Chakrabarty, D. (2003).Vaiśeșika- Sūtra of Kaṇāda. New Delhi, India: D.K. Printworld (P) Ltd.

10. Chatterji J. C. (1912).Hindu Realism: Being an Introduction to the Metaphysics of the Nyâya-Vaisheshika System of Philosophy. Allahabad, India: The Indian Press.

11. Curd, P.(2004).The Legacy of Parmenides: Eleatic Monism and Later Presocratic Thought. Las Vegas, United States of America: Parmenides Publishing.

12. Diogenes, L., \& Hicks, R. D. (1925). Lives of eminent philosophers. London: W. Heinemann.

13. Donahue, W. (1994). Kepler's Invention of the Second Planetary Law. The British Journal for the History of Science, 27(1), 89-102. Retrieved April 17, 2020, from www.jstor.org/stable/4027582

14. Engels, F. (1947). Anti-Dühring: Herr Eugen Dühring's Revolution in Science, translated by Emile Burns. Moscow: Progress Publishers. 
15. Garfield, J.L. (1995). The Fundamental Wisdom of the Middle Way: Nāgārjuna'sMūlamadhyamakakārikā .Oxford, UK: Oxford University Press.

16. Goldhaber, A., \& Nieto, M. (1976). The Mass of the Photon. Scientific American, 234(5), 86-97. Retrieved May 6, 2020, from www.jstor.org/stable/24950353

17. Hall, A.R. (1987). Alexandre Koyré and the scientific revolution. History and Technology, 4(1-4), 485496, DOI: $10.1080 / 07341518708581716$

18. Heath, T. (1913).Aristarchus of Samos, the Ancient Copernicus: A History of Greek Astronomy to Aristarchus, Together with Aristarchus's Treatise on the Sizes and Distances of the Sun and Moon. Oxford: Clarendon Press(1997reprint)

19. Hiriyanna M.(1932). Outlines of Indian Philosophy. London, United Kingdom: George Allen and Unwin Ltd.

20. Kahn, C.H. (1979).The art and thought of Heraclitus: An edition of the fragments with translation and commentary. Cambridge, United Kingdom: Cambridge University Press.

21. Kalupahana, D.(1991). Mūlamadhyamakakārikā of Nāgārjuna: the Philosophy of the Middle Way. Delhi, India: MotilalBanarsidas.

22. Karpinski, L. (1945). Copernicus, Representative of Polish Science and Learning. National Mathematics Magazine, 19(7), 343-348. doi:10.2307/3029925

23. Kepler, J., \& Donahue, W. H. (1992).Astronomia Nova, English translation: New Astronomy. Cambridge, England: Cambridge University Press.

24. Kumar, ShashiPrabha.(2019).Categories, Creation and Cognition in Vaiśeșika Philosophy. Singapore: Springer Nature.

25. Krafft F. (1991) The New Celestial Physics of Johannes Kepler. In: Unguru S. (eds) Physics, Cosmology and Astronomy, 1300-1700: Tension and Accommodation. Boston Studies in the Philosophy of Science,126,185-227.Springer, Dordrecht.

26. KvaszLadislav (2012).Galileo,Descartes and Newton-Founders of the language of Physics. ActaPhysicaSlovaca. 62(6), 519614.

27. Lenin, V.I. (1970).Materialism and Empirio- Criticism: Critical Comments on a Reactionary Philosophy. New York, U.S.A.: International Publishers.

28. Marx, K. (1963). Materialism versus Idealism. In H.Selsam and H.Martal (Eds.) Reader in Marxist Philosophy: from the Writings of Marx Engels and Lenin (pp. 45-93).New York, USA: International Publishers.

29. Malladi, A. V. I. N. A. S. H., and S. I. R. I. S. H. A. Potluri. "A study on technologies in cloud-based design and manufacturing." Int. J. Mech. Prod. Eng. Res. Dev 6.8 (2018): 187-192.

30. Newton, Sir Isaac (1952) Mathematical Principles of Natural Philosophy, in Hutchins, R.H.(Ed.)Vol.34 of Great Books of the Western World, Chicago: Encyclopedia Britannica, Inc.

31. Praśastapādabhāṣyaṃ(Padārthadharmasangrahākhyam) of Praśastapādācārya, Sri DurgadharaJha Sharma (ed. and Hindi trans. ) 1977, 2nd edition.Varanasi,India: Sampurnanand Sanskrit University.

32. Ravikumar, A., and J. T. Selvi. "" A study on the future of micro farmers in white revolution in India". "International Journal of Sales \& Marketing Management Research and Development 3.5 (2013): 11-19.

33. Rovelli, C. (2015). Aristotle's Physics: A Physicist's Look. Journal of the American Philosophical Association,1,2340,DOI:10.1017/apa.2014.11 
34. Ruegg, D. S. (1981) .The Literature of the Madhyamaka School of Philosophy in India. Wiesbaden, Germany: Otto harrassowitz.

35. Russell, J. (1964). Kepler's Laws of Planetary Motion: 1609-1666. The British Journal for the History of Science, 2(1), 1-24. Retrieved April 17, 2020, from www.jstor.org/stable/4025081

36. Russo, L.(2013).Archimedes between legend and fact. Lett Mat Int 1, 91-95. https://doi.org/10.1007/s40329-013-0016-y

37. Shapiro, A. (2004). Newton's "Experimental Philosophy". Early Science and Medicine, 9(3), 185-217.Retrieved April15, 2020, from www.jstor.org/stable/B 4130349

38. Sinha, Nandalal(tr.)(1911): The Vaiśeșika- Sütra of Kanāda with the commentary of SankaraMiśraand Extracts from the Gloss of Jayanārāyana together with notes from the Commentary of Chandrakānta and an introduction by the translator,Reprint,Delhi:S.N.Publications. 1986

39. Singh, Alka, and Rohan Benjamin. "An Analysis of Price Forecast \& The Price Level Changes Owing to the Implementation of GST In India." International Journal of Financial Management (IJFM) ISSN (P): 2319-491X; ISSN (E): 2319-4928 Vol 6 (2017): $1-4$.

40. Suresh, N., B. Srinivasa Reddy, and M. Ravindra Gandhi. "Manufacturing and analysis of four-way hacksaw machine by pedaling." International Journal of Industrial Engineering \& Technology (IJIET) 8.2 (2018): 13-20.

41. Taylor,C.(1998).Democritus (mid 5th-4th century BC).In The Routledge Encyclopedia of Philosophy. Taylor and Francis. Retrieved 17 Apr. 2020, from https:// www. rep. routledge.com/articles/biographical/democritus-mid-5th-4th-century-bc/v1.doi:10.4324/9780415249126-A038-1

42. The Vaiśeșika- Sūtra of Kaṇādawith the commentary of SankaraMiśra and Extracts from the Gloss of Jayanārāyana together with Notes from the Commentary of Chandrakānta and an Introduction by the translator. Nandalal Sinha (Eng.trans.) 1923. Allahabad, India: SuhindranathBasu, ThePāṇini Office, Bhavaneśwarī̄śsama.

43. Westfall R.(1993).The Life of Isaac Newton (First Indian ed.). Cambridge, U.K.: Cambridge University Press.

44. Williams, Monier. 2005, Reprint. Sanskrit English Dictionary, Delhi: SharadaPublishingHouse. Google Scholar

45. Wittenburg N., Kroupa P., Famaey B, (2020).The formation of exponential disk galaxies in MOND. The Astrophysical Journal, 890(2),173-231.Retrieved from https:// iopscience. iop.org/ article/10.3847/1538-4357/ab6d73

46. Van Dyck, M. (2006). An archaeology of Galileo's science of motion. (Ghent University. Faculty of Arts and Philosophy, Ghent, Belgium.)Retrieved from https:// www. clps. ugent.be/ sites/default/files/publications/1878592.pdf

47. Vampoulis E. (2010) Archimedes in Seventeenth Century Philosophy. In: Paipetis S., Ceccarelli M. (eds) The Genius of Archimedes -- 23 Centuries of Influence on Mathematics, Science and Engineering. History of Mechanism and Machine Science, vol 11. Springer, Dordrecht.

48. Wiltsche, H.A. Mechanics Lost: Husserl's Galileo and Ihde's Telescope. Husserl Stud 33, 149-173 (2017). https://doi.org/10.1007/s10743-016-9204-x. 


\section{AUTHOR'S PROFILE}

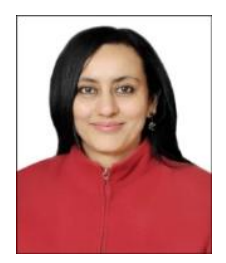

\section{Manjushree Chaudhuri}

Masters in Nuclear Physics from Delhi University, and U.G.C. Net in Education, Manjushree Chaudhuri, was H.O.D. Physics at St. Columba's school, New Delhi, and has also served as P.G.T. Physics at L.G.B. Campus of International School, Geneva and Central School, West Bengal. Presently she is attached to the Physics Department of D.P.S. (R.K.P.) and pursuing her Ph.D in Education from Amity University. She has conducted workshops for teachers and principals at IGNOU for PGDSLM Programme and at Jamia Millia Islamia for the capacity building of teachers under the aegis of MHRD (Ministry of Human Resource and Development) PMMMNMTT scheme and for Delhi Public Schools. The author was the resource person for the review workshop for mapping the e-content of CIET, NCERT corresponding to the themes in the NCERT Textbook for classes XI and XII from $26^{\text {th }}$ June 2018 to $30^{\text {th }}$ June 2018, and also was the resource person for the review workshop for video and multimedia e-content of Physics and Mathematics programme for the web portals of NCERT from $28^{\text {th }}$ May to $30^{\text {th }}$ May 2018 at CIET.

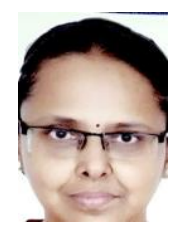

\section{Dr. Seema Agnihotri}

Dr. Seema Agnihotri has 22 years of experience as a teacher educator in different universities of North India. Currently she is working as an Assistant professor -III in the Amity Institute of Education, Amity University, Noida .She was the Principal in the Faculty of Education, ICFAI University, Dehradun from 2008 to 2013.She obtained her Ph.D (Education) from the Department of Education of Delhi University, and has published more than 25 research papers in various reputed and peer reviewed International/National journals and books. She has chaired a number of National and International conferences, and has also been the Co-curricular In charge of the B.ED programme in MERI, GGSIP University, Examination Co-coordinator in the Faculty of Education, ICFAI University and in the Amity Institute of Education, Amity University, Member of Research and Faculty Development Committee in the ICFAI University besides framing the Ph.D curriculum for the Faculty of Education in the ICFAI University. She is a Reviewer of International Journal of Teacher Education, International Journal of Teacher Education And Professional studies and was a member of scientific reviewer committee in the 6th International Conference on Social Sciences 2019,19th - 20th September in Kuala Lumpur, Malaysia, organized by the International Institute of Knowledge management. She has organized Workshops for the Pre-service teachers in February 2013 on " Action Research", a workshop for the inservice teachers in Mahamaya Balak Inter College, Greater Noida on the $27^{\text {th }}$ of November 2014 on " Teacher as a tool of sensitizing students about environmental issues", and a workshop on environmental awareness in Savitri Bai Phule Intercollege on $5^{\text {th }}$ December, 2014.The author was a Resource person for the topic 'Use of School Resources' for 
IGNOU in-service teachers on $19^{\text {th }}$ May 2015, for the In-Service teachers of IGNOU on the theme ' Multicultural

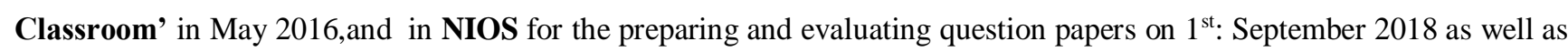
a Resource person in the Workshop for ' Evolving Teaching Strategies for Conservation of Natural Resources' on $19^{\text {th }}$, 2019.Dr. Agnihotri has supervised a number of research work at the post-graduate level, and is supervising at the doctorate level too. She is a member of the All India Association of Teacher Education, the All India Association of Educational Research and the International Forum of Researchers in Education. 
